\title{
Jeffrey Sachs, A New Foreign Policy: Beyond American Exceptionalism (2018)
}

Jonas Ecke

Humanities and Social Sciences, Ashesi University, Berekuso, Ghana

Follow this and additional works at: https://digitalcommons.uri.edu/mgdr

Part of the American Studies Commons, Anthropology Commons, Economics Commons, Marketing Commons, Other Business Commons, Political Science Commons, and the Sociology Commons

\section{Recommended Citation}

Ecke, Jonas (2019) "Jeffrey Sachs, A New Foreign Policy: Beyond American Exceptionalism (2018)," Markets, Globalization \& Development Review: Vol. 4: No. 4, Article 4.

DOI: 10.23860/MGDR-2019-04-04-04

Available at: https://digitalcommons.uri.edu/mgdr/vol4/iss4/4

This Book Review is brought to you for free and open access by DigitalCommons@URI. It has been accepted for inclusion in Markets, Globalization \& Development Review by an authorized editor of DigitalCommons@URI. For more information, please contact digitalcommons-group@uri.edu. 
Jeffrey Sachs, A New Foreign Policy: Beyond American Exceptionalism (2018)

\section{Markets, Globalization \& Development Review}
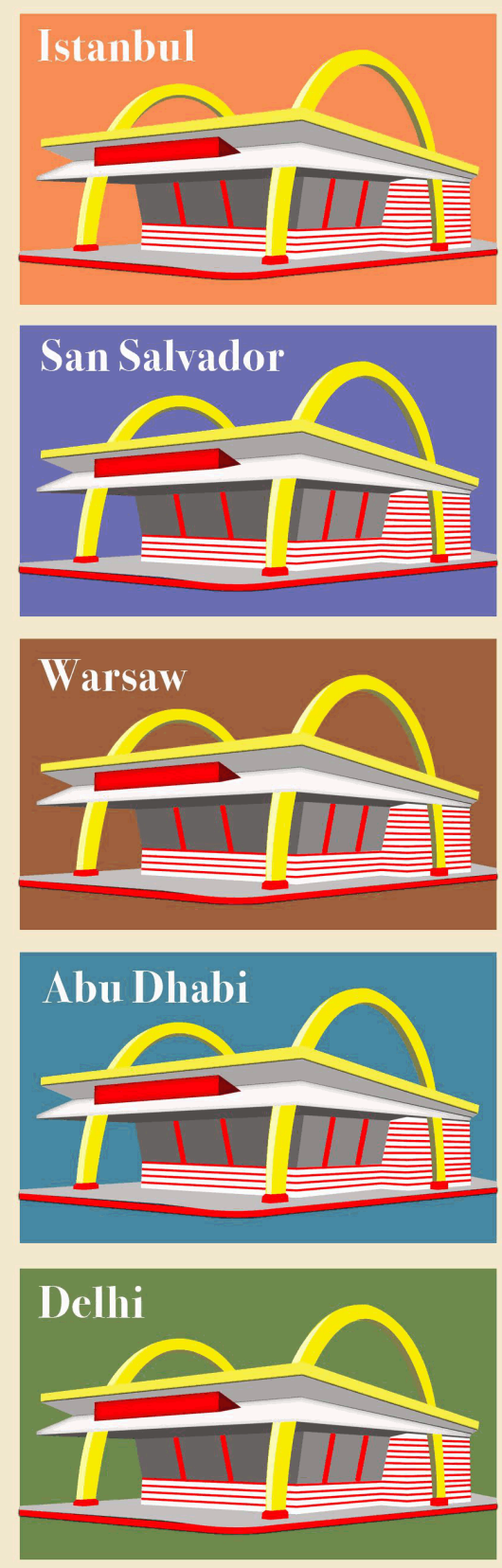
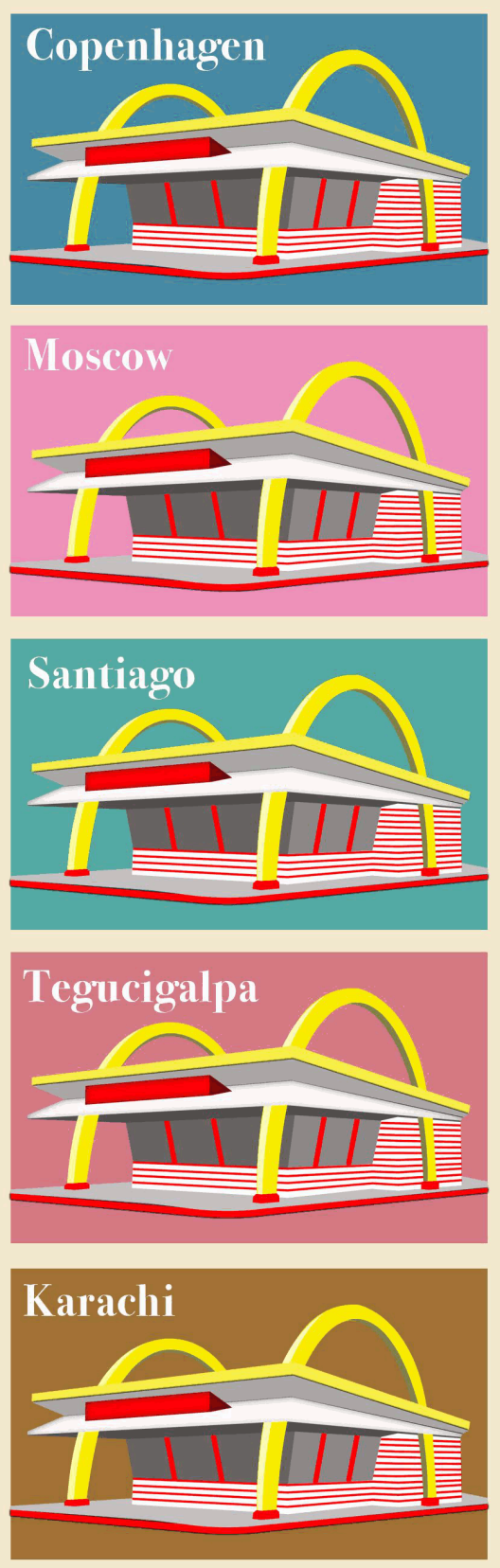
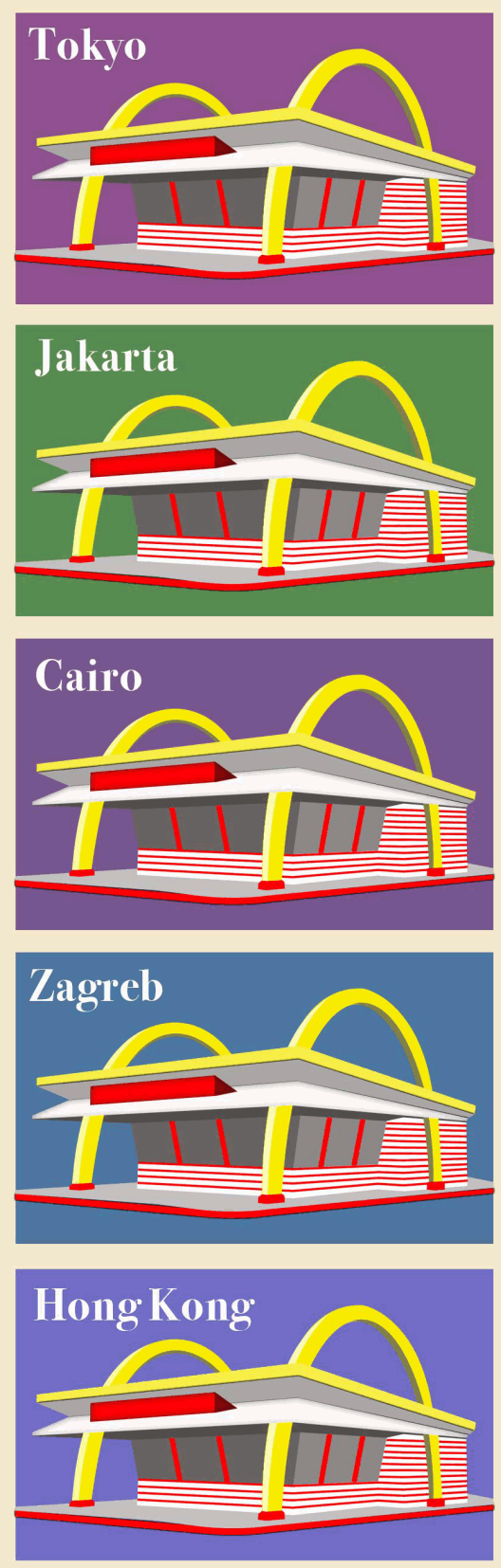

This book review is available in Markets, Globalization \& Development Review: https://digitalcommons.uri.edu/mgdr/ 
Book Review

\section{Jeffrey Sachs, A New Foreign Policy: Beyond American Exceptionalism (2018)}

Defying the academic trend towards more and more specialization, Jeffrey Sachs will not be tied down to only one topic. In his far-seeing and far-reaching book "A New Foreign Policy: Beyond American Exceptionalism", Sachs - a trained economist - addresses the multifaceted nexus between U.S. militarism and exceptionalism, and how it drives policies domestically and around the world. In so doing, he synergizes research findings from the past and present, as well as multiple disciplines, explaining them in a jargon-free language.

Jeffrey Sachs, currently a professor at Columbia University, was a key architect of the Millennium Development Goals promulgated by the United Nations. He has advised several governments such as Bolivia (in 1985), and Russia (1991-1993), during that country's controversial processes of economic liberalization.

U.S. exceptionalism is a cultural tendency and policy-principle that elevates the United States to God's New Israel, "indispensable nation" (Madeline Albright) or the "shining city upon a hill" (Ronald Reagan). The U.S., to remain exceptional, maintains by far the world's biggest military, and it has waged wars across the world. The historian Harry S. Stout, cited by Sachs (p. 2), counted that the U.S. was involved in more than 280 "military interventions and nuclear stand-offs on every corner of the globe", in addition to twenty-nine wars with Native Americans. Exceptionalism and militarism are intertwined: since the wars waged by the U.S. are just by virtue of being fought by an "indispensable nation", they do not receive sufficient domestic scrutiny. Because of the intrinsic virtues of U.S. society, asking deeper questions about the morality of going to war risks being treated as a tautology, at least in the mainstream media.

Against this backdrop, Jeffrey Sachs's analysis offers a refreshing voice, accessible to the mainstream, which raises into question the assumptions that too many journalists and scholars take for granted. The importance of his candor notwithstanding, he overemphasizes the role of the U.S. in the war in Syria, which Sachs depicts as being a U.S.-instigated regime change operation (p. 196). In Syria, it was not the U.S. or any of the other belligerents involved in the war but the Syrian government that was responsible for escalating the conflict in the initial stages and for perpetrating most of the violence against civilians. Wind (2019) has given a credible summary of the precipitating events in Syria. In her own words, the conflict "began when the regime arrested and brutally tortured schoolboys who had 
[created graffiti paintings of] anti-regime slogans on a wall. Public outrage grew when police fired live rounds into the crowds of the boys' families" (paragraph 8). Assessing how many civilians died in Syria is a challenge, but all estimates of civilian casualties in Syria find themselves in agreement that the Syrian regime was responsible for the majority of civilian deaths (The New York Times 2018). According to the estimates of the Syrian Network for Human Rights (SNHRa 2019), the Syrian regime forces and allied Iranian militias caused over 88 percent of the deaths between March 2011 and September 2019. The same organization estimates that Syrian-Russian alliance forces killed 67 percent of all civilians in 2018 (SNHRb 2019, p: 3). In their paper in the renowned medical journal Lancet, Guha-Sapir et al. (2018) make references to data that estimates that almost a quarter of civilian victims (23 percent) in 2016 were children.

The book by Sachs explores the outcomes of military violence, which are characterized by immense suffering and destabilization in many parts of the Middle East, including in Syria. A recent study conducted in Watson Institute of Brown University, for instance, estimate that violence in the context of the "War on Terror" killed between 480,000 and 507,000 people, of which 244,124 to 266,427 were civilians. The number would be greater if one included people who were indirectly killed due to collapsing food, healthcare and energy systems. Only deaths in Iraq, Afghanistan and Pakistan were counted, though the "War on Terror" has more theaters. The study points out that militants - rather than the U.S. and its partners - caused the majority of the direct deaths (Watson Institute for International and Public Affairs 2018).

More indirectly, however, militarism and exceptionalism hinder the U.S. from working together with other nations to address common challenges and defuse global tensions, as well as finding its place in a global geopolitical order and marketplace that is transforming rapidly. Surprisingly, a 2017 study by Meagan and Zeigler (2017, p. 2) from the RAND Corporation shows that terrorism has decreased overall on a global scale. Conflict has increased, however, in areas of civil strife, especially in majority Muslim countries. External "interventions into civil conflicts" are "highly correlated with domestic terrorism". The data demonstrates that the War on Terror, rather than containing it, increased terrorism Such strife and violence are indirect effects of the US militarism and exceptionalism.

Sachs's book draws together recommendation of various domestic and international policy fields, which makes it hard to summarize. For example, other chapters include "The Economic Balance Sheet on 'America First'” (p. 131-136), which explores Donald Trump's trade and fiscal policies, which Sachs characterizes as misdirected. Sachs also addresses the "Economic War with China" ( $p$. 
145-150), as well as the question, "Will Trump hand China the Technological Lead?" (p. 151-158).

In this review, I will focus on selected topics from the book. The following sections summarize two issue areas - regional integration and foreign aid - that are of relevance to MGDR and its parent organization ISMD.

\section{A Global Economy of Regions}

In times in which "America First" has become a governance-mantra, the U.S. is losing out on opportunities for international economic cooperation, which are nowadays based on various projects of regional integration. For example, China draws on its history in Eurasia as it undertakes monumental efforts to reconstruct a modern version of the ancient Silk Road. In so doing, it traces back to the ancient trade routes using modern infrastructure that had connected China by land with the Middle East, Europe, as well as Central and South Asia for almost 2,000 years -until the 1600 s, when such trade came to an end.

Though the "One Belt One Road" or the "Belt and Road Initiative" - which is how China's Silk Road project is officially referred to - might be the most epic and novel of current regional integration projects, there are others with a long history. These include the European Union (EU), the North American Trade Area (NAFTA), African Union $(A U)$ and the Association of Southeast Asian Nations (ASEAN). Sachs hopes for a world in which nations can liberate themselves from outdated "balance-of-power" politics and even the major rivaling countries of the Middle East - i.e., Turkey, Iran and Saudi Arabia - "finally decide that there is far more that unite the Turks, the Arabs, and the Persians, than truly divides them" (p. 166).

Sachs's overall enthusiasm for regional integration and his observations about its relevance to U.S. foreign policy are valid, though not every step towards regional -and, by extension, transregional, economic integration is a positive one. A recent, dramatic case-in-point would be the agreement between the EU and the Mercosur block (Brazil, Argentina, Paraguay and Uruguay), which might expand the market for Brazilian beef and soy, the production of which contributes to deforestation and human rights abuses in Brazil (Watts 2019). There has also been a history of scholarly discussions on the "democratic deficit" of the European Union, which is perhaps considered as the standard-bearer of successful regional integration projects (Follesdal and Hix 2006; Decker 2011).

It is nonetheless noteworthy how the geographical isolation of the U.S. turned from a geostrategic advantage into a disadvantage. Arguably, one of the contributing factors to American exceptionalism was that the Atlantic and Pacific Oceans keep the U.S. far removed from other nations' political turmoil, and from the blowbacks of U.S. 
foreign policy. In an age that is characterized by processes of regional integration, the separation of the U.S. from geopolitical hotspots may turn into a disadvantage. In the interest of U.S. prosperity and worldwide stability, it is reassuring to know that Jeffrey Sachs explains such global developments to audiences, in the U.S. and elsewhere.

\section{Foreign Aid}

Sachs was a leading consultant in the implementation of the Millennium Development Goals, which were surprisingly successful in reducing poverty (McArthur and Rasmussen 2017). He devotes a chapter to foreign aid, his original area of expertise. Sachs presents some stunning statistics that show just how much the U.S. priorities are skewed towards militarism versus uplifting vulnerable people around the world. He points out that the total U.S. aid budget equals about two weeks of Pentagon spending (p. 204) and that the total UN budget amounts to the budget that would be needed to run the U.S. military for about one day and nine hours (p. 182).

It would have been helpful if Sachs could have addressed and argued against some of the common criticisms of foreign aid that cannot be supported by the empirical evidence. Sachs addressed some of the aid criticisms levelled by William Easterly in a review in The Lancet (Sachs 2006). Most notably, more recent evidence suggests that aid may be - contrary to what critics such as Moyo (2009) claim - conducive to economic growth. Writing for the Brookings Institute, Radelet (2017) cites nine studies that correlate growth with foreign aid infusions. He writes that there are additional studies showing the same correlation. It should also be mentioned that there is not necessarily evidence that growth impacts humanitarian well-being. As Kenny (2012, p.190) argues by way of compiling a review of studies, "quality-of-life improvements can be sustained absent GDP growth".

Sachs could have more explicitly referred to such evidence and emphasized some of the non-economic benefits of aid. For example, largely because of a comparatively large-scale global response, the direst predictions on the outcomes of the public health emergencies caused by HIV/AIDS (for instance that HIV/AIDS would kill half of all young adults in South Africa, Botswana and Zimbabwe) did not become true. Remarkable success stories were also recorded in the fight against malaria, polio and Onchozerkose (river blindness).

In his chapter on "global convergence" (p. 43-54), Sachs could have explicitly emphasized that not only economic indices become more similar all over the world, but so do quality of life indicators, as Kenny (2009) has masterfully done. Foreign aid appears to play a role in accelerating such convergence. McArthur and Rasmussen (2017) compared each country's progress in improving their performance in 
regard to the indicators such as child mortality and infectious diseases such as HIV/AIDS. As McArthur and Rasmussen (2017, p.132) calculated, "at least 20.9 million and as many as 30.3 million additional lives were saved" because the Millennium Development Goals accelerated efforts towards poverty reduction. Sub-Saharan Africa accounted for nearly two-thirds of the lives saved. There are other such dramatic success stories. Since 1990, infant deaths have been cut by half, which means that 122 million lives were saved (Gates Foundation in The Guardian 2017).

As Sachs appropriately points out, "(t)here are very few knowledgeable people around to defend it [i.e., development aid], and the recipients it keeps alive don't vote in US elections" (p. 188). Given that we live in a world in which prosperity still coexists with extreme poverty, and policies to reduce poverty could yield more dramatic success if more funding were available, deadly poverty is a collective moral failure.

Sachs's chapter on foreign aid lacks a sense of moral urgency to increase aid spending to tackle remaining pockets of extreme poverty. Though his defense of aid could have been more spirited, his chapter on aid does succeed in illustrating that foreign aid must be an integral part of Sachs's envisioned "new foreign policy".

\section{Concluding Comments}

Overall, the book provides a very comprehensive roadmap towards creating a foreign policy that would make the U.S. a responsible and reliable partner, perhaps even a champion, in creating global prosperity and peace. Some politicians in the U.S. - such as congresswoman Ilhan Omar and presidential contender Senator Bernie Sanders - are becoming more explicit in formulating more constructive pro-peace policies. It would be interesting to hear more about how Sachs would take on the entrenched domestic and international interests that have made implementing such policies so difficult in the past.

"A New Foreign Policy" is well worth the read. Donald Trump has escalated military operations around the world. With regards to U.S. long-range bombing, Cornell University political scientist Matthew Evangelista shared with this reviewer that " $(W)$ e have seen its vast increase during the Obama years and again in the early Trump administration". Neoconservatives still beat the drums for war with Iran. In such times, the U.S. needs a scholar who speaks to broad audiences to point out the many direct and indirect harms caused by exceptionalism and militarism, as well as tangible alternative strategies to engage the world in less belligerent ways. Fittingly, Sachs dedicates the book two of "the great truthtellers in our midst" (p. 222): Noam Chomsky and Bernie Sanders. It is a proud tradition that Sachs emulates. 


\section{References}

Decker, Frank (2011), "Governance Beyond the Nation-state. Reflections on the Democratic Deficit of The European Union," Journal of European Public Policy, 9 (2), 256-72. https://doi.org/10.1080/13501760110120255

Financial Times (2015), "The UN Obsession with Global Targets for Poverty," Financial Times, September 25, (accessed on June 1, 2020), [available at: https://www.ft.com/content/7287e72a-637711e5-9846-de406ccb37f2].

Follesdal, Andreas and Simon Hix (2006), Why There is a Democratic Deficit in the EU: A Response to Majone and Moravcsik," JCMS Journal of Common Market Studies, 44 (3), 533-66. https://doi.org/10.1111/j.1468-5965.2006.00650.x

Guha-Sapir, Debarati, Benjamin Schlüter, Jose Manuel RodriguezLlanes, Louis Lillywhite and Madelyn Hsiao-Rei Hicks (2018), "Patterns of Civilian and Child Deaths due to War-related Violence in Syria: A Comparative Analysis from the Violation Documentation Center Dataset," 2011-16. The Lancet Global Health, 6, (accessed on June 1, 2020), [available at: https://www.thelancet.com/action/showPdf?pii=S2214109X\%2817\%2930469-2].

Kenny, Charles (2012), Getting Better: Why Global Development Is Succeeding--And How We Can Improve the World Even More. New York City: Basic Books.

McArthur, John W. and Krista Rasmussen (2017), "Change of Pace: Accelerations and Advances During the Millennium Development Goal Era," World Development, 105, May, (accessed on June 1, 2020), [available at: https://www.sciencedirect.com/science/article/pii/S0305750X173 04230].

Moyo, Dambisa (2009), Dead Aid: Why Aid Is Not Working and How There Is a Better Way for Africa. New York City: Farrar, Straus and Giroux.

Radelet, Steve (2017), "Once More into the Breach: Does Foreign Aid Work?" Brookings Institute, Future Development, May 8, (accessed on June 1, 2020), [available at: https://www.brookings.edu/blog/futuredevelopment/2017/05/08/once-more-into-the-breach-doesforeign-aid-work/].

Sachs, Jeffrey (2006), "How to Help the Poor: Piecemeal Progress or Strategic Plans?" Perspectives, 367 (9519). https://doi.org/10.1016/S0140-6736(06)68561-9

Smith, Meagan and Sean M. Zeigler (2017), "Terrorism Before and After 9/11 - A More Dangerous World?" Research and Politics, 
October-December: 1-8. (accessed on June 1, 2020), [available at:

https://journals.sagepub.com/doi/pdf/10.1177/205316801773975 7].

Syrian Network for Human Rights (SNHRa) (2019), "Civilian Death Toll," SN4HR, (accessed on June 1, 2020), [available at: http://sn4hr.org/blog/2018/09/24/civilian-death-toll/].

Syrian Network for Human Rights (SNHRb) (2019), "Documenting the Death of 6,964 Civilians in Syria in 2018," Relief Web, January 1 , (accessed on June 1, 2020), [available at: https://reliefweb.int/sites/reliefweb.int/files/resources/Docume nting the Death of 6964 Civilians in Syria in 2018 en.pdf].

The New York Times (2018), "How Syria's Death Toll Is Lost in the Fog of War," The New York Times, April 13, (accessed on June 1, 2020), [available at: https://www.nytimes.com/2018/04/13/world/middleeast/syriadeath-toll.html].

The Guardian (2017), "How Bill and Melinda Gates Helped Save 122m Lives and What They Want to Solve Next," The Guardian, February 12, (accessed on June 1, 2020), [available at: https://www.theguardian.com/world/2017/feb/14/bill-gatesphilanthropy-warren-buffett-vaccines-infant-mortality].

Watts, Jonathan (2019), "We Must Not Barter the Amazon Rainforest for Burgers and Steaks," The Guardian, July 2, (accessed on June 1, 2020), [available at: https://www.theguardian.com/environment/commentisfree/20 19/jul/02/barter-amazon-rainforest-burgers-steaks-brazil].

Watson Institute for International and Public Affairs of Brown University (2018), "Human Cost of the Post-9/11 Wars: Lethality and the Need for Transparency," (accessed on June 1, 2020), [available at:

https://watson.brown.edu/costsofwar/files/cow/imce/papers/2018 /Human\%20Costs\%2C\%20Nov\%208\%202018\%20CoW.pdf].

Wind, Ella (2019), "Syria, The United States, and The Left," New Politics, 2 (66), (accessed on June 1, 2020), [available at: https://newpol.org/issue post/syria-the-united-states-and-theleft]. 